\title{
DESAIN STRATEGI PEMBELAJARAN BAHASA ARAB di MI
}

\author{
Khotijah \\ Institut Agama Islam Negeri (IAIN) Metro \\ Jl. Ki Hajar Dewantara 15A Iring Mulyo Kota Metro \\ nawalatikhotijah@yahoo.com
}

\begin{abstract}
There are two crucial things essence in the learning proses. They are teachers and students. The teachers are the main actors in teaching, and students are main actors in learning. Basically learning is a process of change, from not knowing to know, less good to be good trough interaction between individuals and the environment. In school learning proses is a continous series of activities, planed, integrated which gives overall characteristics in the learning process. Skill and ways of teaching teachers in managing the learning process is called learning strategies. A teacher must design learning with the right strategy so that the material presented to students can be delivered maximally and please them. Whether or not the use of a particular strategy in learning depends on the goals, material, character of learners and teachers. So there is no specific strategy that is best and suitable for all learning situations and conditions. But it is the strategies that fit the learning needs. The characteristics of primary school children should be a special consideration in designing of learning strategies.
\end{abstract}

Keyword :Design Strategy, Arabic Learning, Madrasah Ibtidaiyah

\begin{abstract}
Abstrak
Pada hakikatnya dalam proses kegiatan belajar mengajar (KBM) itu terdiri dari dua hal yang kursial yaitu guru dan murid. Guru sebagai pemeran utama dalam proses mengajar, sedangkan murid adalah pemeran utama dalam proses belajar. Belajar pada dasarnya merupakan proses perubahan, dari tidak tahu menjadi tahu, kurang baik menjadi lebih baik melalui interaksi antar individu dan lingkungan. Dalam pembelajaran di sekolah, proses merupakan rangkaian kegiatan yang berkelanjutan, terencana, berkesinambungan dan terpadu yang secara keseluruhan memberikan karakteristik dalam proses pembelajaran. Keterampilan dan gaya mengajar seorang guru dalam mengatur proses pembelajaran disebut dengan strategi pembelajran. Seorang guru harus mendesain pembelajaran dengan strategi yang tepat agar materi/ pesan yang disampaikan kepada peserta didik dapat tersampaikan dengan maksimal dan terasa menyenangkan. Cocok atau tidaknya penggunaan strategi tertentu dalam pembelajaran bergantung pada tujuan, materi, karakter peserta didik, dan guru itu sendiri. Sehingga tidak ada strategi tertentu yang terbaik dan cocok untuk segala situasi dan kondisi pembelajaran, namun strategi yang cocok adalah strategi yang sesuai dengan kebutuhan pembelajaran. Karakteristik anak MI harus menjadi pertimbangan khusus dalam mendesain strategi pembelajaran.
\end{abstract}

Kata Kunci: Desain Strategi, Pembelajaran Bahasa Arab, Madrasah Ibtidaiyah 


\section{Pendahuluan}

Seorang guru/pengajar memiliki tugas utama yaitu menyelenggarakan pembelajaran dan pendidikan. Agar kegiatan itu dapat berjalan dengan baik, efektif, dan tercapai tujuan yang diinginkan seorang guru harus mengetahui hakikat kegiatan belajar, mengajar. Apa yang harus diajarkan, untuk apa diajarkan, kepada siapa diajarkan, bagaimana cara mengajarkan, dan bagaimana mengukur keberhasilan semua harus direncanakan dan diatur sedemikian rupa.

Strategi pembelajaran adalah bentuk dari oprasionalisasi metode, media dan sarana dalam berbagai bentuknya yang memuat gaya dan seni yang dilakukan guru dalam proses pembelajaran. Strategi pembelajaran juga meliputi aturan-aturan, langkah-langkah serta sarana yang prakteknya akan diperankan dan akan dilalui dari pembukaan sampai penutupan dalam proses pembelajaran di dalam kelas guna merealisasikan tujuan pembelajaran. Oleh karena itu harus didesain dengan sebaik-baiknya.

Kemampuan mendesain strategi pembelajaran merupakan keterampilan yang tidak terpisah dari proses pembelajaran. Seorang guru bukan hanya dituntut mengajar dengan baik tetapi juga harus mampu merencanakan proses pembelajaran dengan baik yaitu sejalan dengan tujuan dan kompunen-kompunen yang lain seperti materi, peserta didik dan lain sebagainya. Apalagi pelajaran bahasa Arab bagi kebanyakan peserta didik terutama Madrasah Ibtidaiyah (MI) bukanlah materi yang mudah dan menyenangkan. Rata-rata mereka menganggap pelajaran yang sulit dan membosankan.

Berbagai macam aturan dan keterampilan bahasa Arab dalam silabus harus disampaikan dalam waktu yang terbatas secara bersamaan merupakan tantangan tersendiri bagi guru bahasa Arab. Di samping itu karakter anak MI baik secara fisik maupun psikis perlu difahami dengan baik oleh seorang guru. Kompleksitas tersebut tidak boleh dijadikan hambatan bagi guru, tetapi harus menjadi pemacu untuk lebih cermat mendesain strategi pembelajaran sesuai dengan tuntutan zaman dan karakter peserta didik agar pelajaran bahasa Arab bukan saja menjadi pelajaran yang mudah difahami akan tetapi juga menyenangkan peserta didik.

\section{Pembahasan}

\section{Pengertian Strategi Pembelajaran}

Kata strategi berasal dari bahasa Yunani strategia yang berarti ilmu perang atau panglima perang. Berdasarkan pengertian tersebut stategi dapat diartikan sebagai suatu seni dalam merancang oprasi peperangan, baik dari segi posisi dan siasat peperangan. Pengertian strategi mengalami perkembangan hingga digunakan dalam 
hampir setiap disiplin ilmu. Dalam konteks pengajaran strategi diartikan sebagai garis-garis besar haluan sebagai dasar dalam mencapai tujuan yang telah ditentukan dalam pembelajaran. ${ }^{1}$

Pendapat lain menjelaskan strategi pembelajaran adalah rencana, aturanaturan dan langkah-langkah yang secara praktek akan diperankan dalam proses belajar mengajar dalam rangka mencapai tujuan tertentu. ${ }^{2}$

Menurut Abdul Majid strategi pembelajaran adalah perencanaan yang berisi tentang rencana kegiatan pembelajaran yang didesain untuk mencapai tujuan pendidikan tertentu yang mencakup penggunaan pendekatan, metode dan teknik, bentuk media, sumber belajar, pengelompokan antar peserta didik, serta upaya pengukuran terhadap proses, hasil dan dampak kegiatan pembelajaran. $^{3}$

Menurut Oemar Hamalik strategi pengajaran adalah keseluruhan metode dan prosedur dalam proses belajar mengajar untuk mencapai tujuan tertentu. ${ }^{4}$

Berasarkan pendapat di atas, strategi

Iskandarwassid, Dadang Sunendar, Strategi Pembelajaran Bahasa, (Bandung: Remaja Rosdakarya, 2013), h. 2

2 Bisri Mustafa, Abdul Hamid, Metode dan Strategi Pembelajaran Bahasa Arab, (Malang: UIN Maliki Press, 2012), h. 68

3 Abdul Majid, Strategi pembelajaran, (Bandung: remaja Rosdakarya, 2013), h. 6

4 Oemar Hamalik, Proses Belajar Mengajar, (Jakarta: Bumu Aksara, 2013), h. 201 pembelajaran merupakan suatu langkah yang disusun secara sistematis dan terencana, dan akan dipraktekkan dalam proses kegiatan belajar mengajar guna mencapai suatu tujuan pembelajaran. Dalam pembelajaran bahasa Arab sendiri strategi disusun sedemikian rupa agar materi/ pesan yang hendak disampaikan dapat disampaikan secara maksimal sehingga tujuan yang telah dirumuskan dapat tercapai. Strategi dalam pembelajaran bahasa Arab meliputi beberapa hal yaitu pembelajaran unsur bahasa Arab (mufradat, tarkib) dam strategi pembelajaran keterampilan bahasa Arab (istima, kalam, , qira'ah, kitabah).

\section{Jenis Strategi Pembelajaran Secara Umum}

Dalam memilih dan menentukan strategi pembelajaran diperlukan pendekatan tertentu. Pendekatan merupakan sudut pandang atau titik tolak untuk memahami seluruh persoalan dalam proses pembelajaran sebagai gambaran dari cara berpikir dan sikap seorang pengajar dalam menjalankan dan melaksanakan tugasnya sebagai pengajar dan pendidik. Berikut ini akan dijelaskan jenis-jenis strategi pembelajaran berdasarkan klasifikasinya:

a. Strategi pembelajaran berdasarkan penekanan komponen dalam program pengajaran:

1) Strategi yang berpusat pada pengajar 
Strategi ini disebut juga sebagai strategi tradisional dan merupakan strategi paling tua karena dalam hal ini mengajar diartikan sebagai proses menyampaikan informasi kepada peserta didik, dengan demikian tekanan strategi berada pada pengajar itu sendiri yang mempunyai peranan yang dominan dalam pembelajaran. Dalam proses pembelajaran seperti ini siswa cenderung menjadi pasif. Strategi yang berpusat pada pengajar ini disebut dengan teacher centre strategies.

2) Strategi yang berpusat pada peserta didik

Strategi ini disebut juga dengan student center strategies, dengan titik tolak pada sudut pandang yang memberi arti bahwa mengajar adalah usaha menciptakan sistem lingkungan yang mengoptimalkan kegiatan belajar, dalam hal ini peserta didik bukan sebagai objek tetapi menjadi subjek aktif. Strategi ini memberikan kesempatan seluas-luasnya kepada peserta didik untuk berperan aktif dalam kegiatan pembelajaran.
Pengajar/ Guru dalam hal ini berperan sebagai fasilitator dan motivator serta membenatu peserta didik untuk mengembangkan dirinya secara utuh sehingga pengajar harus mengetahui potensi-potensi masing-masing peserta didiknya. Salah satu contoh teknik penyajian yang sesuai dengan strategi ini adalah, inkuiri, diskusi, kerja kelompok, eksperimen, sosiodrama dan penemuan ( discovery).

3) Strategi yang berpusat pada materi pengajaran

Strategi ini dsebut juga dengan material center strategis, yang bertitik tolak bahwa belajar adalah usaha untuk memperoleh dan menguasai informasi. Dalam hal ini, strategi dipusatkan pada materi pembelajaran, dan memiliki kecenderungan pada dominasi kognitif, sementara pendidikan afektif dan psikomotorik kurang mendapat perhatian.

Strategi yang berpusat pada materi ini berbanding lurus dengan pesatnya perkembangan teknologi dan ilmu pengetahuan yang disertai arus globalisasi yang berakibat pengajar tidak lagi menjadi sumber informasi. Lembaga pendidikan juga bukan menjadi satusatunya sumber informasi, karena bisa didapatkan melalui media cetak dan 
media elektronik. Teknik yang sesuai dengan strategi ini adalah tutorial, modular dan lain-lain.

b. Strategi Pembelajaran berdasarkan kegiatan Pengolahan pesan atau materi

1) Strategi Pembelajaran Ekspositoris

Strategi pembelajaran ini berbentuk penguraian, baik berupa bahan tertulis maupun penjelasan verbal. Materi diolah secara tuntas oleh pengajar sebelum dismapaikan di kelas dengan tujuan agar semua komponen materi sampai kepada siswa secara langsung.

2) Strategi pembelajaran Heuristik

Strategi ini memberi kesempatan kepada peserta didik untuk berperan dominan dalam proses pembelajaran. Peserta didik diarahkan oleh pengajar untuk mencari dan menemukan sendiri fakta dan konsep secara aktif, sampai peserta didik dapat memberikan kesimpulan yang tepat.

c. Strategi pembelajaran berdasarkan pengolahan pesan atau materi

1) Strategi pembelajaran Deduksi

Dalam strategi ini pesan diolah mulai dari hal yang umum menuju hal khusus, hal-hal yang abstrak kepada hal-hal yang nyata, konsep-konsep abstrak kepada contoh yang kongrit.

2) Strategi pembelajaran induksi

Dalam strategi ini pengolahan pesan dimulai dari hal-hal yang khusus menuju yang lebih umum.

d. Strategi pembelajaran berdasarkan cara memproses penemuan

1) Strategi pembelajaran Ekspositoris

Strategi pembelajaran ini berbentuk penguraian yang dapat berupa bahan tertulis atau penjelasan verbal dengan diolah secara tuntas sebelumnya oleh pengajar agar informasi dapat tersampaikan kepada peserta didik secara langsung.

2) Strategi pembelajaran Discovery

Dalam strategi ini pengajar harus meningkatkan aktivitas peserta didik dalam pembelajaran, dengan beberapa tahapan yaitu mengamati, mencerna, mengerti, menggolong-golongkan, menduga, menjelaskan, mengukur dan membuat kesimpulan. ${ }^{5}$

\section{Strategi Pembelajaran bahasa Arab}

Berikut ini penjelasan seputar strategi pemblajaran bahasa Arab yang meliputi pembelajaran unsur bahasa (mufradat dan tarkib) dan strategi pembelajaran keterampilan bahasa ( istima', kalam,

${ }^{5}$ Iskandarwassid, Dadang Sunendar, Strategi Pembelajaran.., h. 25-33 
qira'ah, kitabah).

a. Strategi Pembelajaran mufradat (kosa kata)

Para ahli bersepakat bahwa pembelajaran mufradat sangat penting bagi siswa yang sedang memepelajari bahasa Arab karena merupakan tuntutan dan syarat dasar dalam pembelajaran bahasa asing. Kiranya sulit bahkan tidak mungkin siswa akan dapat menguasai keterampilan berbahasa dengan baik jika tidak memperoleh penguasaan mufradat yang baik. Penguasaan mufradat bukan hanya sekedar hafal kosa kata tanpa mengetahui penggunaannya dalam komunikasi sesungguhnya baik secara lisan maupun tertulis. Dalam pembelajaran mufradat, guru harus menyiapkan kosa kata yang tepat bagi siswanya. Oleh karena itu guru harus berpegang teguh pada prinsip dan kriteria pemilihan mufradat yang akan di ajarkan kepada pembelajar asing (li ghairi naatiqiin biiha), adalah sebagai berikut:

1) Tawatur artinya memilih mufradat yang sering digunakan, misalkan mufradat yang sesuai dengan 'amal yaumiyah

2) Tawazzu' artinya memilih mufradat yang banyak digunakan di Negaranegara Arab

3) Mataahiyah artinya memilih kata yang digunakan dalam bidang-bidang tertentu
4) Ulfah artinya memilih kata yang familiar, seperti kata syamsun lebih terkenal dari kata dzuka'

5) Syumuul artinya memilih kata yang dapat digunakan dalam berbagai bidang .

6) Ahammiyah, artinya memilih kata-kata yang dibutuhkan siswa

7) 'Urubah memilih kata-kata Arab walaupun ada bandingannya dalam bahasa lain, missal kata haatif daripada tilfun. ${ }^{6}$

Adapun cara menjelaskan mufaradat adalah sebagai berikut:

1) Menampilkan benda, misal menampilkan pena, buku, pensil

2) Dengan peragaan tubuh, misal guru membuka pintu ketika menerangkan kalimat kتحت الباب

3) Dengan bermain peran, misal guru memerankan orang yang sakit perut dengan memegang perut dan مبط mengucapkan mufradat

4) Menyebutkan antonimnya

5) Menyebutkan sinonimnya

6) Menyebutkan kelompok kata, misal menjelaskan kata عائلة dengan أولاد، زوج mnyebutkan kata

7) Menyebutkan kata dasar dan kata bentukannya

8) Menjelaskan makna kata dengan menjelaskan maksudnya

9) Mengulang-ngulang bacaan

\footnotetext{
${ }^{6}$ Bisri Mustafa, Abdul Hamid, Metode dan Strategi.., h. 68-69
} 
10) Mencari kata dalam kamus

11) Menerjemahkan kata kedalam bahasa siswa, ini adalah cara terakhir dan hendaknya guru tidak tergesa-gesa menggunakan cara ini. ${ }^{7}$

Mengingat pentingnya pembelajaran mufradat dalam pembelajaran bahasa Arab, karena syarat dasar untuk dapat menguasai keterampilan bahasa Arab, maka seorang guru bahasa Arab harus mengetahui tentang prinsip pemilihan mufradat dan cara mengajarkannya. Dalam hal ini agar siswa tidak hanya sekedar hafal mufradat, tetapi juga dapat menggunakan mufradat yang sudah dipelajarinya dalam bahasa aktif baik secara lisan maupun tertulis.

b. Strategi Pembelajaran Tarkib (Tata bahasa)

Telah menjadi kesepakatan bahwa penguasaan kaidah nahwu bukan merupakan tujuan pembelajaran bahasa Arab, melainkan sebagai sarana yang membantu para siswa agar mampu berbicara, membaca dan menulis dengan tepat dan benar.

Ada dua model pembelajaran nahwu yaitu sebagai berikut:

1) Model Qiyasiy (deduktif) yaitu dengan menyajikan kaidah kemudian memberikan contohnya. Adapun strategi yang sesuai dengan model pembelajaran ini adalah sebagai berikut:

a) Guru memulai pelajaran dengan menggunakan tema tertentu

b) Guru menjelaskan kaidah-kaidah

c) Siswa memahami dan menghafal kaidah-kaidah nahwu

d) Guru memberikan contoh-contoh yang berkaitan dengan kaidah yang sedang dipelajari

e) Guru member kesimpulan

f) Siswa diminta mengerjakan soal latihan

2) Model Isttiqraiy (induktif) yaitu pengajaran dimulai dengan membrikan contoh-contoh kemudian disimpulkan menjadi kaidah nahwu. Adapun strategi yang sesuai dengan model ini adalah sebagai berikut:

a) Guru memulai pelajaran dengan menentukan tema tertentu

b) Guru memberikan contoh-contoh sesuai tema

c) Siswa secara bergantian diminta membaca contoh-contoh yang telah ditampilkan guru

d) Guru menjelaskan kaidah-kaidah yang terdapat dalam contoh

e) Guru bersama siswa membuat kesimpulan

f) Siswa diminta mengerjakan latihan. $^{8}$ 
Kedua model pembelajaran nahwu yang telah dijelaskan diatas mempunyai ciri khas masing-masing, dan tentu strategi pengajarannya pun berbeda. Dalam kitab nahwu yang sudah familiar digunakan dikalangan pesantren ada beberapa kitab yang sesuai dengan model pembelajarn nahwu tersebut, mislakan kitab jurumiyah sesuai dengan model pembelajaran Qiyasiy dan kitab Nahwu wadhih sesuai dengan model pembelajarn Istiqraiy, namun dikalangan pesantren model ini lebih dekat dikenal dengan metode qowaaid wa tarjamah dan metode mubasyirah.

\section{c. Strategi pembelajaran Istima'}

Istima' merupakan sarana dan tahap pertama yang digunakan manusia untuk berhubungan dengan sesama. Istima' merupakan maharah dasar yang harus dikuasai untuk dapat menguasai unsure bahasa dan tiga maharah bahasa berikutnya. Sehingga strategi pembelajaran istima' harus diperhatikan.

Adapun strategi pembelajaran istima' yang dapat digunakan oleh guru adalah sebagai berikut:

1) Memilih percakapan yang sesuai dengan tingkat kebahasaan dan jenjang siswa, serta yang bisa menyenangkan siswa. Guru menceritakan kepada siswa, siswa mendengarkan dengan baik kemudian guru member pertanyaan kepada siswa.

2) Guru menyampaiakan cerita yang cocok dan mudah bagi siswa, kemudian secara bergantian siswa diminta menceritakan kembali dengan bahasa mereka.

3) Guru melatih seorang siswa untuk mendengarkan cerita pendek atau mendengarkan dari kaset, kemudian menceritakan kembali didepan kelas di depan teman-temannya kemudian didiskusikan.

4) Guru member perintah dengan satu kali ucapan tanpa mengulang, kemudian meminta beberapa anak untuk mengulangi perintah dan siswa yang ain diminta mengerjakannya. Misal: خذ الكتاب

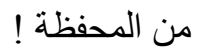

5) Mengajar istima' dengan bermain peran (rool playing)

6) Mengajar istima' dengan bisik berantai

7) Guru membacakan satu tema bacaan pendek dan mudah, setelah itu memberikan pertanyaan kepada siswa secara lisan tanpa membetulkan jika jawaban salah. Kemudian mengulangi bacaan, agar siswa mengingat kembali dan mengoreksi jawabannya sendiri.

8) Guru menyampaikan satu kata atau dua kata yang tidak cocok dalam kalimat, kemudian bertanya pada siswa tentang pendapat mereka mengenai materi yang telah mereka dengar.

9) Guru memperbanyak pertanyaan lisan dan meminta siswa menjawabnya. 
10) Guru menampilkan bahan istima' dengan menggunakan media elektronik. ${ }^{9}$

\section{d. Strategi Pembelajaran kalam}

Pada dasarnya bahasa adalah sarana untuk berkomunikasi dengan orang lain baik secara lisan maupun tertulis. Kemampuan seseorang dalam menyusun kata-kata yang baik dan jelas mempunyai dampak yang besar karena dapat mengungkapkan pikiran-pikirannya atau dalam rangka memenuhi kebutuhannya.

Berbicara/ kalam adalah salah satu keterampilan berbahasa yang harus dikuasai seorang siswa, untuk itu seorang guru harus mempunya strategi yang jitu agar para siswa terlatih untuk menggunakan bahasa yang dipelajarinya secara aktif. Berikut ini akan dipaparka strategi pemeblajaran kalam yang yang bisa dipraktikan oleh guru:

1) Guru mengucapkan beberapa nama benda yang ada di dalam kelas dengan menggunakan bahasa Arab, kemudian siswa diminta untuk menirukannya , kemudian guru melanjutkan dengan mengaitkan nama-nama benda tersebut dengan situasi di kelas. Misalkan:

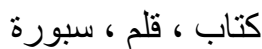

Kemudian dikaitkan dengan kata lain, seperti:

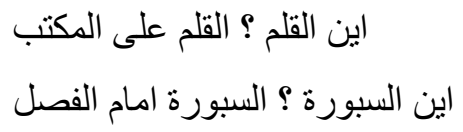

2) Jika sudah mungkin untuk dikembangkan guru bisa melanjutkan dengan cerita yang menggambarkan kegiatan siswa atau menampilkan cerita bergambar yang mengandung alur percakapan, kemudian meminta siswa untuk bertanya seperti pemeran gambar tersebut.

3) Guru meminta siswa untuk memilih gambar tertentu dan mendeskripsikannya

4) Melatih kalam disertai dengan rangkaian kegiatan dan gerakan. ${ }^{10}$ Misalnya:

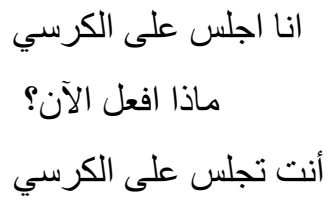

e. Strategi Pembelajaran Membaca (Qira'ah)

1) Definisi keterampilan Membaca Membaca merupakan salah satu keterampilan berbahasa yang tidak mudah dan tidak sederhana, tidak sekedar membunyikan huruf-huruf atau kata-kata akan tetapi sebuah keterampilan yang melibatkan berbagai kerja akal dan pikiran.

Keterampilan membaca (maharah al-qiraa'ah/ reading skill) adalah kemampuan mengenali dan memahami 
isi sesuatu yang tertulis (lambinglambang tertulis) dengan melafalkan atau mencernanya di dalam hati. Membaca hakekatnya adalah proses komunikasi antara pembaca dengan penulis melauli teks yang ditulisnya, maka secara langsung di dalamnya ada hubungan kognitif antara bahasa lisan dengan bahasa tulis. ${ }^{11}$

Pada hakekatnya membaca adalah melihat dan memahami isi dari apa yang tertulis dengan melisankan atau di dalam hati dan mengeja atau melafalkan apa yang tertulis. Jadi, membaca mencangkupdua kemahiran sekaligus, yaitu mengenali symbolsimbol tertulis yang ada di dalamnya dan memahami isinya. ${ }^{12}$

Kemahiran membaca mengandung dua aspek atau pengertian. Pertama, mengubah lambang tulis menjadi bunyi. Kedua, menangkap arti dari seluruh situasi yang dilambangkan dengan lambang-lambang tulis dan bunyi tersebut. $^{13}$

2) Beberapa Jenis Membaca dan Strategi Pengajarannya

\footnotetext{
Acep Hermawan, Metodologi Pemelajaran Bahasa Arab, (Bandung: Remaja Rosdakarya, 2011) h. 143.

12 Abd. Wahab Rosyidi, Mamlu'atul Ni'mah, Op. Cit, h. 95

${ }^{13}$ Ahmad Fuad Effendy, Op. Cit, h. 166
}

Dua aspek kemahiran membaca, yaitu:

a) Membaca Keras (Al-Qira'ah aljahriyyah)

Dalam kegiatan membaca keras, yang terutama ditekankan adalah kemampuan membaca dengan:

(1) Menjaga ketepatan bunyi bahasa Arab, baik dari segi makhraj maupun sifat-sifat bunyi yang lain;

(2) Irama yang tepat dan ekspresi yang menggambarkan perasaan penulis;

(3) Lancer, tidak tersendat-sendat dan terulang-ulang;

(4) Memperhatikan tanda baca atau tanda grafis (pungtuasi)

b) Membaca dalam hati (Al-Qiraah ash-shamitah)

Dalam kegiatan membaca dalam dalam hati, perlu diciptakan suasana kelas yang tertib sehingga memungkinkan siswa berkonsentrasi kepada bacaannya.

c) Membaca Cepat (Al-Qiraah assari'ah)

Dalam membaca cepat ini siswa tidak diminta memahami rincianrincian isi teks, tetapi cukup dengan pokok-pokonya saja.

d) Membaca rekreatif (al- Qiraah alistimta'iyyah)

Dalam hal ini, bahan bacaan dipilihkan yang ringan popular, baik 
ditinjau dari segi isi maupun susunannya. Biasanya berupa cerita pendek dan novel.

e) Membaca analistik (Al-Qiraah at-tahiliyah)

Tujuan membaca dalam membaca ini adalah untuk melatih siswa agar memiliki kemampuan mencari informasi dari bahan tertulis. $^{14}$

f. Strategi Pembelajaran Menulis (Kitabah)

$\begin{array}{lr}\text { 1) Definisi } & \text { Keretampilan } \\ \text { Menulis } & \\ \text { Menulis } & \text { merupakan }\end{array}$

kemampuan menggunakan polapola bahasa secara tertulis untuk mengungkapkan suatau gagasan atau pesan. $^{15}$

Menurut Acep Hermawan keterampilan menulis (maharah alkitabah/ writing skill) adalah kemampuan dalam mendeskripsikn atau mengungkapkanisi pikiran, mulai dari aspek yang sederhana seperti menulis kata-kata sampai kepada aspek yang kompleks yaitu mengarang. ${ }^{16}$

Kemahiran menulis mempunyai dua aspek: pertama

\footnotetext{
${ }^{14}$ Ibid, h. $169-172$

15 Abd. Wahab Rosyidi, Mamlu'atul Ni'mah, Pembelajaran Bahasa.. , h. 97

16 Acep Hermawan, Metodologi Pembelajaran.., h. 151
}

kemahiran membentuk huruf dan menguasai ejaan; kedua kemahiran melahirkan fikiran dan perasaandengan tulisan.

2) Tahap-tahap latihan Menulis

a) Latihan Kebahasaan (Tamrinat Lughawiyah)

Dalam hal ini ditempuh dua cara, yaitu rekombinasi adalah latihan menggabungkan kalimat-kalimat yang mulanya berdiri sendiri menjadi satu kalimat panjang. Sedangkan transformasi adalah latihan mengubah bentuk kalimat, dari kalimat positf menjadi kalimat negative, kalimat berita menjadi kalimat tanyadan sebagainya.

b) Mencontoh

Pada tahap pertama siswa belajar dan melatih diri menulis dengan tepat sesuai dengan contoh. Kedua, siswa belajar mengeja dengan benar. Ketiga, siswa berlatih menggunakan bahasa Arab yang benar.

c) Reproduksi

Reproduksi adalah menulis berdasarkan apa yang telah dipelajari secara lisan. Dalam hal ini siswa sudah mulai dilatih menulis tanpa ada model.

d) Imlak

Imlak di samping melatihkan penulisan ejaan juga melatih penggunaan 'gerbang-telinga' untuk membedakan makhraj al-hurf. 
e) Mengarang terpimpin

Pada tahap ini, siswa mulai dikenalkan dengan penulisan alenia, walaupun sifatnya masih terpimpin.

f) Mengisi formulir, bagan, dan sejenisnya

g) Mengarang bebas

Tahap ini merupakan tahap yang melatih siswa mengutarakan isis hatinya dengan memilih katakata dan pola kalimat secra bebas. ${ }^{17}$

4. Pembelajaran Bahasa Arab di Madrasah Ibtidaiyah (MI)

a) Karakteristik Anak MI

Menurut teori Pieget anak usia ini termasuk pada perkembangan operasional kongret. Periode sensori-motor ( $0-2,0$ tahun ), periode pra-operasional $(2,0-7,0$ tahun ), periode operasional konkret ( 7,0 - 11,0 tahun ), periode opersional formal ( $11,0$ - dewasa $).{ }^{18}$

Dalam tahap ini anak hanya bisa memahami benda-benda kongret yang bisa dilihat dan sangat sulit untuk diajak disiplin dan berkonsentrasi dengan satu hal. Mereka akan cepat bosan dan mengalihkan perhatiannya kepada hal-hal lainnya yang dianggap menarik dan menyenangkan.

17 Ahmad Fuad Effendy, Metodologi Pengajaran.., h. 183-189

18 https://ilmuwanmuda.wordpress.com diunduh 1 Mei 2018
Pemahaman guru terhadap karakteristik ini menjadi sangat penting bagi guru agar bisa menyesuaikan dengan kondisi mereka baik dalam proses pembelajarannya, tujuannya, caranya, maupun respon terhadap sikap mereka. Respon yang tepat merupakan langkah positif dalam proses pembelajaran dan sangat bermakna bagi peserta didik. Respon positif akan menumbuhkan semangat bagi mereka, sebaliknya respon negative akan membunuh semangat dan minat terhadap pelajaran yang diajarkan oleh guru.

Di antara karakteristik anak MI menurut Scott Ytreberg yang dikutip Ainin (dalam Nurhidayati dan Nur Anisah Ridwan) adalah: (1) anak-anak belajar sambil bekerja, (2) anak-anak memperoleh pemahaman melalui gerakan (isyarat tangan), (3) anakanak suka bermain dan mempelajari sesuatu yang mereka senangi, (4) anak-anak sudah dapat berargumentasi (membantah), (5) kosa kata anak-anak tidak sama dengan kosa kata orang dewasa. ${ }^{19}$ Pendapat juga menyatakan bahwa karakteristik anak-anak SD/MI adalah: (1) senang bermain, (2) senang bergerak, (3) senang bekerja dalam kelompok, (4) senang merasakan atau melakukan sesuatu secara langsung. ${ }^{20}$

19 Nurhidayati dan Nur Anisah Ridhwan, Strategi Pembelajaran Bahasa Arab untuk Anak, (Malang: Bintang Sejahtera Press, 2016) h. 27.

${ }^{20} \mathrm{http}$ ///sabrinariz.blogspot.com. Diunduh 1 Mei 2018. 
b) Tujuan dan Ruang Lingkup pelajaran bahasa Arab MI

1) Tujuan

Mata pelajaran Bahasa Arab merupakan suatu mata pelajaran yang diarahkan untuk mendorong, membimbing, mengembangkan, dan membina kemampuan serta menumbuhkan sikap positif terhadap bahasa Arab baik reseptif maupun produktif. Kemampuan reseptif yaitu kemampuan untuk memahami pembicaraan orang lain dan memahami bacaan. Kemampuan produktif yaitu kemampuan menggunakan bahasa sebagai alat komunikasi baik secara lisan maupun tulis. Kemampuan berbahasa Arab serta sikap positif terhadap bahasa Arab tersebut sangat penting dalam membantu memahami sumber ajaran Islam yaitu al-Qur'an dan hadis, serta kitab-kitab berbahasa Arab yang berkenaan dengan Islam bagi peserta didik.

Untuk itu, bahasa Arab di madrasah dipersiapkan untuk pencapaian kompetensi dasar berbahasa, yang mencakup empat keterampilan berbahasa yang diajarkan secara integral, yaitu menyimak, berbicara, membaca, dan menulis. Meskipun begitu, pada tingkat pendidikan dasar (elementary) dititikberatkan pada kecakapan menyimak dan berbicara sebagai landasan berbahasa.
Pada tingkat pendidikan menengah (intermediate), keempat kecakapan berbahasa diajarkan secara seimbang. Adapun pada tingkat pendidikan lanjut (advanced) dikonsentrasikan pada kecakapan membaca dan menulis, sehingga peserta didik diharapkan mampu mengakses berbagai referensi berbahasa Arab. Mata pelajaran Bahasa Arab memiliki tujuan sebagai berikut:

a. Mengembangkan kemampuan berkomunikasi dalam bahasa Arab, baik lisan maupun tulis, yang mencakup empat kecakapan berbahasa, yakni menyimak (istima'), berbicara (kalam), membaca (qira'ah), dan menulis (kitabah).

b. Menumbuhkan kesadaran tentang pentingnya bahasa Arab sebagai salah satu bahasa asing untuk menjadi alat utama belajar, khususnya dalam mengkaji sumber-sumber ajaran Islam.

c. Mengembangkan pemahaman tentang saling keterkaitan antara bahasa dan budaya serta memperluas cakrawala budaya. Dengan demikian, peserta didik diharapkan memiliki wawasan lintas budaya dan melibatkan diri dalam keragaman budaya. ${ }^{21}$

2) Ruang Lingkup Bahasa Arab MI

Ruang lingkup pelajaran Bahasa Arab di Madrasah Ibtidaiyah meliputi tema-tema

\footnotetext{
${ }^{21}$ http://lughotudhod.blogspot.com. Diunduh
} 1 Mei 2018. 
tentang perkenalan, peralatan madrasah, pekerjaan, alamat, keluarga, anggota badan, di rumah, di kebun, di madrasah, di laboratorium, di perpustakaan, di kantin, jam, kegiatan sehari-hari, pekerjaan, rumah, dan rekreasi. ${ }^{22}$

c) Prinsip Dasar Strategi Pembelajaran Bahasa Arab di MI

Pemilihan strategi pembelajaran bahasa Arab MI hendaknya memperhatikan prinsip-prinsip berikut:

1) Prinsip bahasa dan pendidikan

2) Prinsip psikologis

3) Prinsip sosial budaya. ${ }^{23}$

Selanjutnya Nurhayati dan Nur Anisah juga menjelaskan bahwa prinsip bahasa dan pendidikan adalah hendaknya bahasa yang diajarkan adalah bahasa fusha kontemporer, dapat membantu siswa untuk mengucapkan bunyi-bunyi bahasa Arab secara benar, memperhatikan problema yang dihadapi, memperhatikan aspek gradual, menghindari aspek gramatika secara mendetail, menggunakan pendekatan fungsional komunikatif, dan vareasi materi.

Prinsip psikologi adalah hendaknya memperhatikan tingkat pemahaman siswa, memberikan kesan dan membantu pemikiran siswa, disesuaikan dengan bakat, meningkatkan motivasi dan minat,

\footnotetext{
${ }^{22}$ Ibid

${ }^{23}$ Nurhidayati dan Nur Anisah Ridhwan, Strategi Pembelajaran.., h. 19.
}

memperhatikan perbedaan individu, memperhatikan umur, variasi materi dan ditulis lengkap dengan tanda baca, memotivasi siswa untuk menggunakan bahasa Arab, saling melengkapi dalam menyajikan materi, materi ajar memudahkan siswa untuk beradabtasi dengan orang Arab, dan membantu siswa untuk membentuk norma-norma yang diinginkn.

Prinsip sosial budaya hendaknya materi ajar bernuansa Arab Islam, budaya disesuaikan dengan minat siswa, memperhatikan hazanah intelektual orang Arab, gradual dalam menyampaikan materi budaya, memperhatikan perubahan sosial budaya yang terjadi di Arab, membekali siswa dengan konsep-konsep Islam yang relevan dengan kondisi mereka, menghormati budaya dan perbedaan lain yang sesuai dengan umur siswa, dan membantu siswa dalam membangun tradisi sosial.

Prinsip tersebut harus diperhatikan dengan tidak mengabaikan salah satu diantaranya, karena ketiganya saling terkait. Prinsip bahasa dan pendidikan secara aplikatif hendaknya diutamakan sisi pengucapan dan diaplikasikan dalam bentuk kalimat lengkap dan untuk komunikasi. Sedangkan prinsip psikologi menentukan pilihan terhadap bahasa yang sesuai dengan tingkat kecerdasan siswa, variasi bahasa harus menarik minat belajar siswa. Dalam hal ini topic dan bentuk tulisan juga sangat menentukan. Untuk anak MI bentuk tulisan 
hendaknya tidak terlalu kecil dengan harakat lengkap dan dibantu dengan gambar-gambar yang sesuai dengan materi. Sedangkan prinsip sosial budaya hendaknya materi yang diajarkan mengutamakan dengan lingkungan sosial budaya siswa agar mudah diaplikasikan dalam komunikasi mereka.

\section{SIMPULAN}

Dari pemahasan tersebut dapat kita simpulkan bahwa:

1. Desain strategi pembelajaran bahasa Arab adalah bentuk rencana pembelajaran dari konsep sampai pelaksanaan pembelajaran untuk tercapainya tujuan yang diinginkan.

2. Pembelajaran bahasa Arab di MI harus didesain sesuai dengan karakteristik peserta didik.

3. Tujuan pembelajaran di MI adalah membina kemampuan bahasa anak secara produktif maupun reseptif.

4. Dalam mendesain strategi pembelajaran bahasa Arab hendaknya memperhatikan prinsip bahasa dan pendidikan, psiklogis, dan budaya.

\section{Daftar Pustaka}

Effendy, Ahmad Fuad, Metodologi Pengajaran Bahasa Arab, (Malang: Misykat, 2012)

Hamalik, Oemar, Proses Belajar Mengajar, (Jakarta: Bumu Aksara,
2013)

Hermawan, Acep, Metodologi Pembelajaran Bahasa Arab, (Bandung: Remaja Rosdakarya, 2011)

https://ilmuwanmuda.wordpress.com http://lughotudhod.blogspot.com. http://sabrinariz.blogspot.com.

Iskandarwassid, dan Sunendar, Dadang, Strategi pembelajaran Bahasa, (Bandung: Remaja Rosdakarya, 2013)

Majid, Abdul, Strategi pembelajaran, (Bandung: remaja Rosdakarya, 2013)

Mustafa, Bisri, dan Hamid, Abdul, Metode dan Strategi Pembelajaran Bahasa Arab, (Malang: UIN Maliki Press, 2012)

Nurhidayati dan Ridhwan, Nur Anisah, Strategi Pembelajaran Bahasa Arab untuk Anak, (Malang: Bintang Sejahtera Press, 2016)

Rosyidi, Abd. Wahab, dan Ni'mah, Mamlu'atul, Pembelajaran Bahasa Arab, (Malang: UIN-MALIKI PRESS) 